\title{
Determinan Kejadian Infeksi Saluran Pernapasan Akut pada Balita 3-5 Tahun di Wilayah Kerja Puskesmas Ujong Fatihah Kabupaten Nagan Raya
}

\author{
${ }^{1}$ Siti Suharni, ${ }^{2}$ Jun Musnadi Is \\ Fakultas Kesehatan Masyarakat Universitas Teuku Umar, Aceh, Indonesia \\ Corresponding author's email: junmusnadi@utu.ac.id
}

Submitted: 18/02/2019 Revised: 21/03/2019 Accepted: 04/04/2019

How to cite this article:

Suharni, S., \& Is, J. (2019). Determinan kejadian infeksi saluran pernapasan akut pada balita 3-5

tahun di wilayah kerja Puskesmas Ujong Fatihah Kabupaten Nagan Raya. J-KESMAS, 6(1), 28-40

\begin{abstract}
Abstrak
Berdasarkan hasil data rekam medik dari Puskesmas Ujong Fatihah pada tahun 2015 jumlah penderita ISPA sebanyak 664 kasus. Pada tahun 2016 jumlah penderita ISPA sebanyak 816 kasus, jumlah penderita ISPA tahun 2017 dari Januari-September sebanyak 527 kasus. Tujuan Penelitian ini adalah untuk mengetahui Determinan Kejadian Infeksi Saluran Pernapasan Akut Pada Balita 3-5 Tahun Di Wilayah Kerja Puskesmas Ujong Fatihah Kabupaten Nagan Raya.Penelitian ini telah dilaksanakan di Wilayah Kerja Puskesmas Ujong Fatihah Kabupaten Nagan Raya pada tanggal 23 Oktober - 13 Desember 2017 dengan jumlah populasi 527 ibu yang memiliki balita 3-5 tahun yang mengalami ISPA dengan jumlah sampel 84 responden, dianalisis dengan kuantitatif.Hasil penelitian adanya hubungan antara faktor status gizi balita $\left(\mathrm{P}_{\text {value }}=0,000<\alpha=0,05\right)$, faktor berat badan lahir $\left(\mathrm{P}_{\text {value }}=\right.$ $0,000<\alpha=0,05)$, faktor keberadaan perokok $\left(\mathrm{P}_{\text {value }}=0,000<\alpha=0.05\right)$ dengan kejadian ISPA.Kesimpulan dalam Adanya hubungan faktor status gizi balita, faktor berat badan lahir, faktor keberadaan perokok dengan kejadian ISPA.Diharapkan kepada ibu balita agar selalu menjaga status gizi balita, serta menjauhkan balita dari keluarga yang merokok agar balita yang mengalami ISPA ringan tidak mengalami ISPA berat. Selanjutnya rutin melakukan pengecekan kesehatan anak ke puskesmas agar ISPA pada balita dapat di sembuhkan.
\end{abstract}

\section{Kata Kunci}

Status Gizi, Berat Badan Lahir, Keberadaan Perokok, ISPA

\begin{abstract}
Based on the result of medical record data from Puskesmas Ujong Fatihah in 2015, the number of ARI sufferers is 664 cases. In 2016, the number of ARI sufferers is 816 cases, the number of ARI patients in 2017 from January to September is 527 cases. The purpose of this study was to determine the Determinants of Acute Respiratory Infections Infection In Toddlers 3-5 Years At Work Area Puskesmas Ujong Fatihah Nagan Raya District.This research has been conducted in Ujong Fatihah Health Center Working Area of Nagan Raya Regency on 23rd October to 13th December 2017 with
\end{abstract}


population 527 mothers who have children under five 3-5 years who have ARI with sample size 84 respondents, analyzed with quantitative. The result of the research was the correlation between nutrition status factor of balita (Pvalue $=0,000<\alpha=0,05$ ), birth weight factor (Pvalue $=0,000<\alpha=$ 0,05 ), presence factor of smoker (Pvalue $=0,000<\alpha=0.05$ ) with incidence of ARI.Conclusion in The existence of correlation factor of nutrition status of toddler, birth weight factor, existence factor of smoker with incident of ARI. It is expected that the mother of toddlers to always keep the nutritional status of children under five, as well as keep toddlers from families who smoke for toddlers who have mild ISPA does not experience severe ARI. Furthermore, routine checks the health of the child to the puskesmas for ARD in toddlers can be cured.

\section{Keywords}

Nutritional Status, Birth Weight, Presence of Smokers, ARI

\section{Pendahuluan}

Sampai dengan tahun 2013, penyakit ISPA merupakan penyebab utama kematian balita di dunia. Diperkirakan ada 1,8 juta atau 20\% dari kematian anak diakibatkan oleh pneumonia, melebihi kematian akibat AIDS, malaria dan tuberkulosis. Menurut definisi, pneumonia adalah infeksi jaringan paru-paru (alveoli) yang bersifat akut. Penyebabnya adalah bakteri, virus, jamur, pajanan bahan kimia atau kerusakan fisik dari paru-paru, maupun pengaruh tidak langsung dari penyakit lain. Bakteri yang biasa menyebabkan pneumonia adalah Streptococcus dan Mycoplasma pneumonia, sedangkan virus yang menyebabkan pneumonia adalah adenoviruses, rhinovirus, influenza virus, respiratory syncytial virus (RSV) dan para influenza virus (Anwar, 2014).

Penyakit ISPA (Infeksi Saluran Pernafasan Akut) merupakan salah satu contoh penyakit infeksi yang menular pada pernafasan dan merupakan penyakit infeksi akut menular yang masih menjadi isu kesehatan global di semua Negara. Riset WHO (World Health Organization) pada tahun 2010 menyebutkan bahwa \pm 13 juta balita di dunia meninggal akibat ISPA setiap tahun dan sebagian besar kematian tersebut terdapat di Negara berkembang (Kemenkes RI, 2012).

Banyak faktor yang dapat berpengaruh terhadap meningkatnya kejadian ISPA pada balita, baik dari aspek individu anak, perilaku orang tua (ibu), maupun lingkungan. Kondisi lingkungan fisik rumah yang tidak memenuhi syarat kesehatan dan perilaku penggunaan bahan bakar dapat meningkatkan risiko terjadinya berbagai penyakit seperti TB, katarak, dan pneumonia. Rumah yang padat penghuni, pencemaran udara dalam ruang akibat penggunaan bahan bakar padat (kayu bakar/ arang), dan perilaku merokok dari orangtua merupakan faktor lingkungan yang dapat meningkatkan kerentanan balita terhadap pneumonia (Listyowati, 2013).

Hampir 4 juta orang meninggal akibat ISPA setiap tahun, 98\%-nya disebabkan oleh infeksi saluran pernapasan bawah (WHO, 2010). Insiden menurut umur balita diperkirakan 0,29 episode per anak/tahun di negara berkembang dan 0,05 episode per anak/ tahun di negara maju. Kasus terbanyak terjadi di India (43 juta), China (21 juta) dan Pakistan (10 juta) dan Bangladesh, Indonesia, Nigeria masing-masing 6 juta episode. Dari semua kasus yang terjadi di masyarakat, 7-13\% kasus berat dan memerlukan perawatan rumah sakit. Episode batukpilek pada balita di Indonesia diperkirakan 2-3 kali per tahun (Kemenkes RI, 2011). 
Berdasarkan hasil laporan Kementerian kesehatan Indonesia pada tahun 2012 jumlah penderita ISPA adalah sebanyak 549.708 kasus, dimana tertinggi berada di provinsi Jawa Barat yaitu sebanyak 189.233 kasus (Kemenkes RI, 2013). Selanjutnya pada tahun 2013 jumlah penderita ISPA adalah sebanyak 571.547 jiwa, dimana tertinggi berada di provinsi Jawa Barat yaitu sebanyak 164.839 kasus (Kemenkes RI, 2014). Selanjutnya pada tahun 2014 jumlah penderita ISPA adalah sebanyak 657.490 jiwa, dimana tertinggi berada di provinsi Jawa Barat yaitu ssebanyak 197.654 kasus (Kemenkes RI, 2015).

Berdasarkan hasil laporan Dinkes Aceh pada tahun 2012 jumlah penderita ISPA adalah sebanyak 52.928 kasus, jumlah penderita yang ditemukan dan ditangani sebanyak 2.395 kasus, dimana tertinggi berada di Kabupaten Aceh Utara yaitu sebanyak 6.116 kasus dan jumlah penderita yang ditemukan dan ditangani terendah di Kota Subussalam sebanyak 976 kasus. Sedangkan Nagan Raya berada pada urutan ke 19 dari 23 Kabupaten yang ada di Aceh (Dinkes Aceh, 2013). Selanjutnya pada tahun 2013 jumlah penderita ISPA adalah sebanyak 427.258 kasus, jumlah penderita yang ditemukan dan ditangani tertinggi di Kabupaten Aceh Utara sebanyak 2.102 kasus (Dinkes Aceh, 2014).

Berdasarkan hasil laporan Dinkes Nagan Raya pada tahun 2014 jumlah balita sebanyak 13.222 balita, sedangkan jumlah balita yang mengalami ISPA di Kabupaten Nagan Raya adalah sebanyak 39\% (Dinkes Nagan Raya, 2014). Pada tahun 2015 jumlah balita 13.256balita, sedangkan jumlah balita penderita ISPA di Kabupaten Nagan Raya adalah sebanyak 37\% (Dinkes Nagan Raya, 2015). Pada tahun 2016 jumlah balita 16.041 balita, sedangkan jumlah balita penderita ISPA di Kabupaten Nagan Raya adalah sebanyak 26\% (Dinkes Nagan Raya, 2016).

Berdasarkan hasil data rekam medik dari Puskesmas Ujong Fatihah pada tahun 2015 jumlah penderita ISPA sebanyak 664 kasus. Pada tahun 2016 jumlah terjadi peningkatan jumlah penderita ISPA menjadi 816 kasus (Puskesmas Ujong Fatihah, 2016). Pada tahun 2017 sebanyak 527 kasus dari Januari-September (Puskesmas Ujong Fatihah, 2017).

Berdasarkan pengamatan dilapangan penulismengidentifikasi hasil wawancara dengan 8 orang ibu balita peneliti mengetahui bahwa 3 orang responden balitanya mengalami ISPA karena ketahanan tubuh yang kurang baik disebabkan status gizi balita kurang. Selanjutnya 3 orang responden balitanya mengalami ISPA karena berat badan balita saat lahir rendah yaitu dibawah $2,5 \mathrm{~kg}$. Kemudian 2 orang responden balitanya mengalami ISPA disebabkan karena ayah balita merokok didalam rumah dan didekat balita.

\section{Tinjauan Pustaka}

\section{Infeksi Saluran Pernafasan Akut}

Menurut Darmawan dalam Rusnaini (2013), Istilah Infeksi Saluran Pernapasan Akut (ISPA) meliputi tiga unsur yakni infeksi, saluran pernafasan, dan akut, dimana pengertiannya sebagai berikut:

1. Infeksi adalah masuknya kuman atau mikroorganisme ke dalam tubuh manusia dan berkembang biak sehingga menimbulkan gejala penyakit.

2. Saluran pernafasan adalah organ mulai dari hidung hingga alveoli beserta organ adneksanya seperti sinus-sinus, rongga telinga tengah dan pleura. 
3. Infeksi Akut adalah Infeksi yang langsung sampai dengan 14 hari. Batas 14 hari diambil untuk menunjukkan proses akut meskipun untuk beberapa penyakit yang dapat digolongkan dalam Infeksi Saluran Pernafasan Akut (ISPA) proses ini dapat berlangsung lebih dari 14 hari.

\section{Balita}

Menurut Sutomo. B. dan Anggraeni. DY, (2010), Balita adalah istilah umum bagi anak usia 1-3 tahun (batita) dan anak prasekolah (3-5 tahun). Saat usia batita, anak masih tergantung penuh kepada orang tua untuk melakukan kegiatan penting, seperti mandi, buang air dan makan. Perkembangan berbicara dan berjalan sudah bertambah baik. Namun kemampuan lain masih terbatas.

\section{Determinan ISPA}

Dalam segitiga epidemiologi (Epidemiologi Triagle) menggambarkan hubungan tiga komponen penyebab penyakit yaitu host, agen/agent dan lingkungan/environment (dibentuk segitiga). Sakit terjadi karena interaksi antara agent, host and environment (Maryani dan Muliani, 2010). Berdasarkan segitiga epidemiologi tersebut kejadian penyakit pneumonia sebagai berikut:

1. Faktor penyebab (Agent) merupakan penyakit penyebab ISPA yaitu bakteri, virus, jamur protozoa. Penyebab tersering adalah bakteri streptococcus pneumoniae/ pneumococcus dan hemophilus influenzae type $b$.

2. Faktor Manusia (Host) biasanya manusia atau pasien. Host dalam faktor resiko ISPA pada balita meliputi umur, jenis kelamin, status gizi, ASI Eksklusif dan Berat Badan Lahir.

a. Umur

Umur juga dapat mempengaruhi status kesehatan, karena ada kecenderungan penyakit menyerang umur tertentu. Pada usia balita dan usia lanjut rentan terhadap penyakit karena pada usia balita sistem pertahanan tubuhnya belum stabil, sedangkan pada usia lanjut sistem pertahanan tubuhnya sudah menurun (Maryani \& Muliani, 2010). Kejadian ISPA meningkat pada usia Balita. Berdasarkan Riskesdas 2013 prevalensi tertinggi pada kelompok usia 1-4 tahun. Insidens tertinggi pada usia 12-23 bulan (21,7 permil), usia $24-35$ bulan (21 per mil), $36-47$ bulan (18 per mil), 48-59 bulan (17 per mil) dan $0-11$ bulan $(13,6$ per mil).

b. Status gizi

Status gizi adalah suatu keadaan tubuh yang diakibatkan oleh keseimbangan antara asupan zat gizi dengan kebutuhan. Status gizi dipengaruhi oleh konsumsi makanan dan penggunaan zat-zat gizi dalam tubuh. Tubuh yang memperoleh cukup zat-zat gizi dan digunakan secara efisien akan tercapai status gizi optimal yang pertumbuhan fisik, perkembangan otak, kemampuan kerja dan kesehatan secara umum pada tingkat setinggi mungkin (Marni, 2014). Kondisi tubuh dengan gizi kurang, akan menyebabkan seorang anak mudah terserang penyakit. Bakteri atau virus mudah masuk dalam tubuh individu dengan ketahanan tubuh atau imunitas yang kurang. Kondisi kurang gizi dapat melemahkan sistem kekebalan tubuh dan pada anak-anak dengan kodisi tersebut dapat melemahkan otot-otot pernafasan sehingga balita dengan gizi kurang akan mudah terserang ISPA dibandingkan balita dengan gizi normal (Maryunani, 2010).

Status gizi adalah keadaan keseimbangan antara asupan (intake) dan kebutuhan (requirement) zat gizi. Untuk menilai status gizi seseorang atau masyarakat dapat dilakukan secara langsung maupun tidak langsung. Penilaian secara langsung yaitu 
dengan cara pemeriksaan fisik, klinis, antropometri dan biokimia. Adapun penilaian secara tidak langsung bisa dilakukan dengan cara melihat angka kematian, angka kelahiran dan data statistik vital lainnya (Soegianto, dkk, 2007).

c. Pemberian ASI Eksklusif

Air Susu Ibu (ASI) merupakan makanan paling baik untuk bayi. ASI mengandung nutrient (zat gizi) yang sesuai untuk bayi seperti lemak, karbohidrat, protein, garam mineral, vitamin ; mengandung zat protektif seperti laktobasilus bifidus, laktoferin, lisozim, komplemen $\mathrm{C} 3$ dan $\mathrm{C} 4$, antistreptokokus ; antibodi seperti immunoglobulin seperti IgA, IgE, IgM, IgG ; imunitas seluler berupa makrofag yang berfungsi membunuh dan memfagositosis mikroorganisme membentuk $\mathrm{C} 3$ dan $\mathrm{C} 4$, lisozim dan laktoferin, serta zat anti alergi. Mekanisme pembentukan antibodi pada ASI adalah apabila ibu mendapat infeksi , maka tubuh ibu akan membentuk antibodi dan akan disalurkan dengan bantuan limfosit. Antibodi pada payudara yang disebut Mammae Associated Immunocompetent Lymphoid Tissue (MALT). Kekebalan terhadap penyakit saluran pernafasan yang ditransfer disebut Bronchus Associated Immunocompetent Lymphoid Tissue (BALT) dan untuk saluran pernafasan ditransfer melalui Gut Associated Immunocompetent Lymphoid Tissue (GALT) (Marni, 2014)

d. Berat Badan Lahir

Berat badan lahir merupakan berat badan bayi yang ditimbang dalam waktu satu jam setelah kelahiran. Klasifikasi neonatus menurut berat badan meliputi berat lahir rendah (kurang dari 2500 gram), berat lahir cukup (antara 2500 gram-4000 gram) dan berat lahir lebih (lebih 4000 gram). BBLR merupakan bayi yang dilahirkan dengan berat badan kurang dari 2500 gram. Penyebab dari BBLR 50\% dikarenakan lahirsecara prematur dan kecil masa kehamilan (small for gestational age). Faktor yang dapat menyebabkan kejadian tersebut antara lain : sosial ekonomi rendah, kurang gizi, merokok sewaktu hamil, bahan teratogen, radiasi dan gangguan metabolisme pada janin. Pada bayi dengan BBLR terdapat beberapa masalah yang sering muncul seperti pola nafas yang tidak efektif berhubungan dengan imaturitas organ pernafasan, ketidakseimbangan nutrisi dari kebutuhan tubuh berhubungan dengan ketidakmampuan absorbsi, resiko ketidakseimbangan suhu tubuh dan resiko infeksi berhubungan dengan sistem kekebalan tubuh yang kurang baik. (Ridha, 2014).

3. Faktor Lingkungan (Environment)

Lingkungan merupakan semua faktor di luar individu yang dapat berupa lingkungan fisik, lingkungan biologis, lingkungan sosial dan lingkungan ekonomi. Faktor lingkungan yang menjadi faktor resiko pneumonia antara lain faktor lingkungan fisik rumah dan sosial ekonomi orang tua. The American Public Health Association merumuskan persyaratan rumah sehat yang bias menjamin kesehatan bagi penghuninya antara lain (Notoadmotjo, 2012):

a. Kepadatan hunian

Menurut Keputusan Menteri Kesehatan RI Nomor 829/Menkes/SK/VII/1999, bahwa luas ruang tidur minimal $8 \mathrm{~m} 2$, tidak dianjurkan digunakan lebih dari 2 orang tidur dalam 1 ruangan kecuali anak di bawah 5 tahun. Penelitian yang dilakukan Yunihasto (2007), menunjukkan lingkungan fisik rumah dengan kepadatan penghuni rumah $<10 \mathrm{~m} 2$ per orang merupakan faktor resiko kejadian ISPA dengan $\mathrm{p}=0,000 \mathrm{OR}=2,2 \mathrm{CI}$ 95\% 1,4-3,6.

b. Ventilasi

Ventilasi adalah proses penyediaan udara dari ruangan baik secara alami atau mekanis. Menurut Menurut KepMenKes RI Nomor 829/Menkes/SK/VII/1999 ventilasi alamiah yang permanen minimal $10 \%$ dari luas lantai. Penelitian Anwar dan Dharmayanti (2014), menunjukkan hasil ventilasi merupakan faktor risiko kejadian ISPA dengan nilai $\mathrm{p}=0,010$ OR=1,16 CI 95\% 1,04-1,30. 


\section{c. Jenis Lantai dan dinding}

Menurut Keputusan Menteri Kesehatan RI Nomor 829/Menkes/SK/VII/1999, salah satu syarat rumah yang baik yang harus dipersiapkan agar memenuhi syarat kesehatan antara lain jenis lantai kedap air dan mudah dibersihkan. Dinding mempunyai ventilasi, bahan kedap air dan mudah dibersihkan. Lantai yang memenuhi syarat adalah yang terbuat dari ubin dan keramik, sedangkan yang terbuat dari tanah tidak memenuhi syarat kesehatan.

d. Keberadaan Perokok

Merokok merupakan salah satu kebiasaan yang lazim ditemui dalam kehidupan sehari-hari. Winniforddalam Rizki (2014) memaparkan bahwa rokok mengandung nikotin yang dapat meningkatkan denyut jantung, tekanan darah sistolik dan diastolik. Peningkatan denyut jantung pada perokok terjadi pada menit pertama merokok dan sesudah 10 menit peningkatan mencapai 30\% sedangkan tekanan sistolik meningkat mancapai $10 \%$.

\section{Metode}

Jenis penelitian ini adalah jenis penelitian survei yang bersifat analitik dengan pendekatan Cross Sectional, dimana variabel bebas dan terikat diteliti pada saat yang bersamaan saat penelitian dilakukan (Notoadmodjo, 2012), yang bertujuan untuk mengetahui Determinan Kejadian ISPA pada Balita umur 3-5 tahun di Wilayah Kerja Puskesmas Ujong Fatihah Kabupaten Nagan Raya.

Populasi dalam penelitian ini adalah seluruh ibu yang memiliki balita umur 3-5 tahun yang mengalami ISPA di Puskesmas Ujong Fatihah Kabupaten Nagan Raya dari bulan JanuariSeptember 2017 yaitu sebanyak 527 ibu. Jumlah keseluruhan yang diambil adalah sebanyak 84 ibu balita 3-5 tahun. Pengambilan sampel dilakukan secara purposive sampling yaitu mengambil responden secara sengaja yang artinya peneliti menentukan sendiri sampel yang diambil berdasarkan pertimbangan tertentu. Sampel yang diambil adalah ibu balita yang pada saat penelitian berada di rumah.

\section{Hasil Penelitian}

\section{Karakteristik Responden \\ Umur Ibu}

Hasil perhitungan frekuensi dan persentase berdasarkan umur responden dapat dilihat pada tabel 4.2 berikut dibawah ini:

Tabel 4.2. Distribusi Responden Berdasarkan Umur Responden di Wilayah Kerja Puskesmas Ujong Fatihah Kabupaten Nagan Raya

\begin{tabular}{ccc}
\hline Umur & Frekuensi (n) & Presentase $\%$ \\
\hline 21-25 Tahun & 8 & 9,5 \\
26-30 Tahun & 10 & 11,9 \\
31-35 Tahun & 7 & 8,3 \\
36-40 Tahun & 28 & 33,3 \\
41-45 Tahun & 17 & 20,2 \\
>45 Tahun & 14 & 16,7 \\
\hline Total & 84 & 100 \\
\hline
\end{tabular}

Sumber: data primer 2017 


\section{Pekerjaan Ibu}

Hasil perhitungan frekuensi dan persentase berdasarkan pekerjaan ibu responden dapat dilihat pada tabel 4.3 berikut dibawah ini:

Tabel 4.3. Distribusi Responden Berdasarkan Pekerjaan Responden di Wilayah Kerja Puskesmas Ujong Fatihah Kabupaten Nagan Raya

\begin{tabular}{ccc}
\hline Pekerjaan & Frekuensi (n) & Presentase \% \\
\hline IRT & 50 & 59,5 \\
PNS & 5 & 6,0 \\
Swasta & 4 & 4,8 \\
Wiraswasta & 25 & 29,8 \\
\hline Total & 84 & 100 \\
\hline
\end{tabular}

Sumber: data primer 2017

\section{Umur Balita}

Hasil perhitungan frekuensi dan persentase berdasarkan umur balita responden dapat dilihat pada tabel 4.4 berikut dibawah ini:

Tabel 4.4. Distribusi Responden Berdasarkan Umur Balita Responden di Wilayah Kerja Puskesmas Ujong Fatihah Kabupaten Nagan Raya

\begin{tabular}{ccc}
\hline Umur Balita & Frekuensi (n) & Presentase \% \\
\hline 3 Tahun & 25 & 29,8 \\
4 Tahun & 25 & 29,8 \\
5 Tahun & 34 & 40,5 \\
\hline Total & 84 & 100 \\
\hline
\end{tabular}

Sumber: data primer 2017

\section{Jenis Kelamin Balita}

Hasil perhitungan frekuensi dan persentase berdasarkan jenis kelamin balita dapat dilihat pada tabel 4.5 berikut dibawah ini:

Tabel 4.5. Distribusi Responden Berdasarkan Jenis Kelamin Balita di Wilayah Kerja Puskesmas Ujong Fatihah Kabupaten Nagan Raya

\begin{tabular}{ccc}
\hline Jenis Kelamin & Frekuensi (n) & Presentase \% \\
\hline Perempuan & 39 & 46,4 \\
Laki-laki & 45 & 53,6 \\
\hline Total & 84 & 100
\end{tabular}

Sumber: data primer 2017 


\section{Status Gizi pada Balita 3-5 Tahun}

Tabel 4.6. Distribusi Responden Berdasarkan Status Gizi Balita 3-5 tahun di Wilayah Kerja Puskesmas Ujong Fatihah Kabupaten Nagan Raya

\begin{tabular}{ccc}
\hline Status Gizi & Frekuensi (n) & Presentase (\%) \\
\hline Baik & 44 & 52,4 \\
Kurang Baik & 40 & 47,6 \\
\hline Total & 84 & 100
\end{tabular}

Sumber: data primer 2017

\section{Berat Badan Lahir}

Tabel 4.7.Distribusi Responden Berdasarkan Berat Badan Lahir Balita3-5 tahundi Wilayah Kerja Puskesmas Ujong Fatihah Kabupaten Nagan Raya

\begin{tabular}{ccc}
\hline Berat Badan Lahir & Frekuensi (n) & Presentase (\%) \\
\hline Normal & 41 & 48,8 \\
Tidak Normal & 43 & 51,2 \\
\hline Total & 84 & 100
\end{tabular}

Sumber: data primer 2017

\section{Keberadaan Perokok}

Tabel 4.8. Distribusi Responden Berdasarkan Keberadaan Perokok di Wilayah Kerja Puskesmas Ujong Fatihah Kabupaten Nagan Raya

\begin{tabular}{ccc}
\hline Keberadaan Perokok & Frekuensi $(\mathrm{n})$ & Presentase $(\%)$ \\
\hline Ada & 50 & 59,5 \\
Tidak Ada & 34 & 40,5 \\
\hline Total & 84 & 100
\end{tabular}

Sumber: data primer 2017

\section{Kejadian ISPA pada Balita 3-5 Tahun}

Tabel 4.9. Distribusi Responden Berdasarkan Kejadian ISPA pada Balita 3-5 tahun di Wilayah Kerja Puskesmas Ujong Fatihah Kabupaten Nagan Raya

\begin{tabular}{ccc}
\hline $\begin{array}{c}\text { Kejadian ISPA pada } \\
\text { Balita 3-5 tahun }\end{array}$ & Frekuensi (n) & Presentase (\%) \\
\hline Berat & 37 & 44,0 \\
Ringan & 47 & 56,0 \\
\hline Total & 84 & 100 \\
\hline
\end{tabular}

Sumber: data primer 2017 
Hubungan Status Gizi Balita dengan Kejadian ISPA pada Balita 3-5 Tahun

Tabel 4.10. Hubungan Status Gizi Balita dengan Kejadian ISPA pada Balita 3-5 tahun di Wilayah Kerja Puskesmas Ujong Fatihah Kabupaten Nagan Raya

\begin{tabular}{|c|c|c|c|c|c|c|c|}
\hline \multirow[t]{3}{*}{ Status Gizi } & \multicolumn{3}{|c|}{ Balita 3-5 tahun } & \multirow{2}{*}{$\frac{\text { Total }}{\boldsymbol{e}}$} & \multirow{2}{*}{\multicolumn{2}{|c|}{$\mathbf{R P}$}} & \\
\hline & Berat & Ring & $P . V$ & & & & \multirow[b]{2}{*}{ CI 95\% } \\
\hline & $\mathrm{f}$ & $\%$ & $\mathrm{f}$ & $\%$ & $\mathrm{f}$ & $\%$ & \\
\hline Baik & 2 & 4,5 & 42 & 95,5 & 44 & 100 & 19,250 \\
\hline Kurang Baik & 3587,5 & & 12,5 & 40 & 100 & & $(1,137-2,288)$ \\
\hline
\end{tabular}

Sumber: data primer 2017

Hubungan Berat Badan Lahir dengan Kejadian ISPA pada Balita 3-5 Tahun

Tabel 4.11. Hubungan Berat Badan Lahirdengan Kejadian ISPA pada Balita 3-5 tahun di Wilayah Kerja Puskesmas Ujong FatihahKabupaten Nagan Raya

\begin{tabular}{|c|c|c|c|c|c|c|c|}
\hline \multirow[t]{3}{*}{$\begin{array}{l}\text { Berat Badan } \\
\text { Lahir }\end{array}$} & \multicolumn{3}{|c|}{$\begin{array}{l}\text { Kejadian ISPA pada } \\
\text { Balita 3-5 tahun Total }\end{array}$} & \multirow{2}{*}{\multicolumn{2}{|c|}{$\mathbf{R P}$}} & \multirow[b]{3}{*}{ CI 95\% } & \\
\hline & \multirow{2}{*}{$\underline{\text { Berat }}$} & \multicolumn{2}{|c|}{ RinganP. Value } & & & & \\
\hline & & $\mathrm{f}$ & $\%$ & $f$ & $\%$ & & \\
\hline$\overline{\text { Normal }}$ & 6 & 14,6 & 35 & 85,4 & 41 & 0.000 & 4,926 \\
\hline Tidak Normal & 3172,112 & 27,9 & 43 & 100 & & $(1,686-4,359)$ & \\
\hline
\end{tabular}

Sumber: data primer 2017

Hubungan Keberadaan Perokok dengan Kejadian ISPA pada Balita 3-5 Tahun

Tabel 4.12. Hubungan Keberadaan Perokokdengan Kejadian ISPA pada Balita 3-5 tahundi Wilayah Kerja Puskesmas Ujong Fatihah Kabupaten Nagan Raya

\begin{tabular}{|c|c|c|c|c|c|c|c|}
\hline$\overline{\text { Keberadaan }}$ & $\overline{\text { Keja }}$ & dian 1 & $\overline{\mathbf{P A ~ p r}}$ & & & & \\
\hline Perokok & Ba & lita 3- & tahun & Total & & & \\
\hline & $\overline{\text { Berat }}$ & $\overline{\text { Ring }}$ & $P . V t$ & & $\mathbf{R P}$ & & \\
\hline & $\mathrm{f}$ & $\%$ & $\mathrm{f}$ & $\%$ & $\mathrm{f}$ & $\%$ & CI 95\% \\
\hline$\overline{\text { Ada }}$ & 34 & 68,0 & 16 & 32,0 & 50 & 100 & 7,707 \\
\hline Tidak Ada & 38,8 & 31 & 91,2 & 34 & 100 & & $(2,729-10,423$ \\
\hline
\end{tabular}

\section{Pembahasan}

Hubungan Status Gizi dengan Kejadian ISPA pada Balita 3-5 Tahun

Berdasarkan hasil uji chi square didapat nilai PValue $=0.000$ dan ini lebih kecil dari $\alpha=0.05$ ( $\mathrm{P}$ Value $=0.000<\alpha=0.05$ ) sehingga diuraikan terdapat hubungan antara status gizi dengan kejadian ISPA di Wilayah Kerja Puskesmas Ujong Fatihah Kabupaten Nagan Raya.Berdasarkan hasil RP 19,250 dapat disimpulkan bahwa status gizi balita memiliki resiko sebesar 19,250 kali dengan kejadian ISPA di Wilayah Kerja Puskesmas Ujong Fatihah Kabupaten Nagan Raya. 
Penelitian di atas sejalan dengan penelitian Hariani (2014) hasil penelitian menunjukan bahwa adanya hubungan antara status gizi dengan kejadian ISPA Pada Anak Dipuskesmas Segeri Pangkepyang ditunjukanya dengan nilai $\mathrm{p}=0,035<=0,05$.

Berdasarkan pengamatan dilapangan bahwa Status gizi balita yang baik lebih banyak mengalami ISPA ringan karena balita ini didukung oleh berat badan yang lahirnya normal dan tidak ada perokok di rumahnya. Akan tetapi balita mengalami ISPA karena faktor lainnya dimana rumah balita adalah rumah yang berdempetan sehingga tidak memiliki jendela untuk keluar masuk udara dan balita jarang berada di luar rumah, lebih sering berada di dalam rumah sehingga pergantian udara di luar tidak dapat di hirup balita dengan baik. Sedangkan balita yang memiliki status gizi baik tetapi mengalami ISPA berat karena kebiasaan ibu yang suka membakar anti nyamuk dan membakar sampah di sekitar rumah membuat balita menghirup asap dan mengalami ISPA berat. Hal ini di ketahui ibu saat melakukan pemeriksaan di rumah sakit.

Balita yang memiliki status gizi kurang baik dan mengalami ISPA berat karena keadaan balita yang rentan dengan penyakit menyebabkan balita mudah mengalami ISPA, selain itu keluarga yang tidak menjaga kebersihan rumah seperti rumah berdebu, ventilasi jendela tidak ada membuat balita menghirup debu dan kurangnya udara segar, hal inilah yang membuat balita mengalami ISPA berat. Hal ini diketahui dari penjelasan dokter yang ibu sampaikan kepada peneliti. Selanjutnya balita yang memiliki status gizi kurang baik tetapi mengalami ISPA ringan karena balita mengalami ISPA akibat rentannya daya tahan tubuh yang mudah terserang penyakit, akan tetapi ibu balita selalu berusaha menjaga kebersihan rumah serta rumah banyak terdapat ventilasi dan jendela sehingga udara segar dapat masuk sellau kedalam rumah.

Penyakit infeksi dengan keadaan gizi kurang merupakan hubungan timbal balik dan sebab akibat. Penyakit infeksi dapat memperburuk keadaan gizi dan keadaan gizi yang kurang dapat mempermudah seseorang terkena penyakit infeksi seperti infeksi pernafasan (Supariyasa, 2012).

\section{Hubungan Berat Badan Lahir dengan Kejadian ISPA pada Balita 3-5 Tahun}

Berdasarkan hasil uji chi square didapat nilai PValue $=0.000$ dan ini lebih kecil dari $\alpha=0.05$ (PValue $=0.000<\alpha=0.05)$ sehingga diuraikan terdapat hubungan antara berat badan lahir dengan kejadian ISPA di Wilayah Kerja Puskesmas Ujong Fatihah Kabupaten Nagan Raya.Berdasarkan hasil RP 4,926 dapat disimpulkan bahwa berat badan lahir memiliki resiko sebesar 4,926 kali dengan kejadian ISPA di Wilayah Kerja Puskesmas Ujong Fatihah Kabupaten Nagan Raya.

Penelitian di atas sejalan dengan penelitian penelitian Fibrilla (2015) Hasil analisis dengan uji chi square dengan tingkat kepercayaan 95\% diketahui ada hubungan antara berat badan lahir dengan ISPA ( $\mathrm{p}$-value $=0.037)$ dan nilai $\mathrm{OR}=4,491(\mathrm{CI}: 1,260-16,006)$ yang berarti bahwa balita yang memiliki usia berisiko tinggi diPuskesmas Bumi Mas Kecamatan BatanghariLampung Timur secara uji statistic memiliki risiko 4,491 kali mengalami ISPA dibandingkan dengan balita yang berat badan lahir normal.

Berdasarkan pengamatan dilapangan bahwa berat badan lahir balita yang normal lebih banyak mengalami ISPA ringan karena balita ini didukung oleh status gizi yang baik serta tidak ada perokok di rumahnya. Akan tetapi balita mengalami ISPA karena faktor lainnya 
dimana balita suka bermain diluar rumah, sering bermain pasir serta meghirup asap kendaraan dan debu-debu yang ada di sekitar rumah terhirup. Hal ini diketahui berdasarkan penjelasan dokter yang ibu ceritakan kepada peneliti. Sedangkan balita yang berat badan lahirnya normal tetapi mengalami ISPA berat karena di rumah balita memiliki perokok yaitu ayah balita merokok didalam rumah dan terhirup oleh balita serta kebiasaan ibu yang suka membakar anti nyamuk membuat balita menghirup asap dan mengalami ISPA berat. Hal ini peneliti ketahui berdasarkan penjelasan ibu kepada peneliti.

Balita yang berat badan lahir tidak normal dan mengalami ISPA berat karena keadaan balita yang rentan dengan penyakit serta hal ini di perkuat dengan status gizi balita yang kurang, selain itu balita juga di biarkan main di luar rumah dan menghirup debu baik dari kendaraan yang lewat maupun debu yang dimainkan balita, hal inilah yang membuat balita mengalami ISPA berat. Hal ini diketahui dari penjelasan dokter yang ibu sampaikan kepada peneliti. Selanjutnya balita yang berat badan lahir tidak normal tetapi mengalami ISPA ringan karena balita mengalami ISPA akibat rentannya daya tahan tubuh yang mudah terserang penyakit akan tetapi balita memiliki status gizi yang baik serta ibu balita selalu berusaha menjaga kebersihan rumah serta rumah banyak terdapat ventilasi dan jendela sehingga udara segar dapat masuk selalu kedalam rumah.

Suyami dan Sunyoto (2014), Riwayat Berat Badan Lahir merupakan faktor yang mempengaruhi system kekebalan tubuh. Pada balita dengan riwayat BBLR yaitu berat badan kurang dari 2500 gram pada saat lahir, menyebabkan system kekebalan tubuh belum sempurna, sehingga daya tahan tubuhnya rendah. Hal ini menyebabkan anak rentan dan mudah terserang penyakit infeksi, seperti infeksi pernafasan.

\section{Hubungan Keberadaan Perokok dengan Kejadian ISPA pada Balita 3-5 Tahun}

Berdasarkan hasil uji chi square didapat nilai PValue $=0.000$ dan ini lebih kecil dari $\alpha=0.05$ (PValue $=0.000<\alpha=0.05$ ) sehingga diuraikan terdapat hubungan antara keberadaan perokok dengan kejadian ISPA di Wilayah Kerja Puskesmas Ujong Fatihah Kabupaten Nagan Raya.Berdasarkan hasil RP 7,707 dapat disimpulkan bahwa keberadaan prokok memiliki resiko sebesar 7,707 kali dengan kejadian ISPA di Wilayah Kerja Puskesmas Ujong Fatihah Kabupaten Nagan Raya.

Hasil penelitian di atas didukung oleh hasil penelitian Ahyanti (2013) dimana didapat hasil adanya hubungan antara perokok dengan kejadian ISPA pada mahasiswa Politeknik Kesehatan Kementerian Kesehatan Tanjung Karang dimana hasil $p$ value $=0,009$.

Berdasarkan pengamatan dilapangan balita yang keberadaan perokok tidak ada di rumah lebih banyak mengalami ISPA ringan karena balita terlindungi dari asap rokok. Akan tetapi balita mengalami ISPA karena faktor lainnya dimana balita sering di bawa ibu bepergian naik angkutan umum, sedangkan di dalam angkutan umum ada orang-orang yang merokok dan asap rokok tersebut terhirup oleh balita dan balita mengalami ISPA

Balita yang memiliki keberadaan perokok dan mengalami ISPA berat karena balita terhirup asap rokok dan hal ini hampir setiap hari dialami balita sehingga membuat balita mengalami ISPA berat, selain itu orangtua juga tidak memindahkan balita atau membawa balita jauhjauh dari orang-orang yang merokok jika mereka merokok dekat balita. Hal ini diketahui dari penjelasan dokter yang ibu sampaikan kepada peneliti. Selanjutnya balita yang memiliki keberadaan prokok dirumah tetapi mengalami ISPA ringan karena ibu balita menjaga 
kesehatan balita dimana saat ayah balita merokok ibu langsung memindahkan balita dan menjaga balita dari aspa rokok. Akan tetapi balita di biarkan bermain di luar rumah sehingga terhidrup debu kendaraan atau debu pasir yang dimainkan balita.

Asap rokok dari orang tua atau penghuni rumah yang satu atap dengan balita merupakan bahan pencemaran dalam ruang tempat tinggal yang seirus serta akan menambah resiko kesakitan dari toksik pada anak-anak. Paparan yang terus-menerus akan menimbulkan gangguan pernafasan terutama memperberat timbulnya infeksi saluran pernafasan akut dan gangguan paru-paru pada saat dewasa. Semakin banyak rokok yang dihisap oleh keluarga semakin besar memberikan resiko terhadap kejadian ISPA, khususnya apabila merokok dilakukan oleh ibu bayi (Kemenkes RI, 2012)

\section{Kesimpulan}

1. Adanya hubungan antara faktor status gizi balita dengan kejadian ISPApada balita 3-5 tahun $\left(\mathrm{P}_{\text {value }}=0.000<\alpha=0.05\right)$

2. Adanya hubungan antara faktor berat badan lahir dengan kejadian ISPApada balita 3-5 tahun $\left(\mathrm{P}_{\text {value }}=0.000<\alpha=0.05\right)$

3. Adanya hubungan antara faktor keberadaan perokok dengan dengan kejadian ISPApada balita 3-5 tahun $\left(\mathrm{P}_{\text {value }}=0.000<\alpha=0.05\right)$

\section{Saran}

1. Diharapkan kepada ibu balita agar selalu menjaga status gizi balita, serta menjauhkan balita dari keluarga yang merokok agar balita yang mengalami ISPA ringan tidak mengalami ISPA berat. Selanjutnya ruti melakukan pengecekan kesehatan anak ke puskesmas agar ISPA pada balita dapat di sembuhkan.

2. Kepada Dinas Kesehatan Kabupaten Nagan Raya diharapkan agar dapat memberikan penyuluhan kepada pihak puskesmas untuk mendata balita yang mengalami ISPA dan memberikan pengarahan kepada petugas kesehatan untuk melakukan program penanggulangan ISPA

3. Kepada peneliti selanjutnya diharapkan penelitian ini dapat dijadikan referensi dalam melakukan penelitian berikutnya dengan variabel berbeda.

\section{DAFTAR PUSTAKA}

Adriani, M dan Wirjatmadi, B. 2012. Peranan Gizi Dalam Siklus Kehidupan. Jakarta : Kencana Prenada Media Group.

Ahyanti, M., Artha B.S.D. 2013. Hubungan Merokok dengan Kejadian ISPA pada Mahasiswa PoliteknikKesehatan Kementerian Kesehatan Tanjungkarang. Jurnal Kesehatan Masyarakat; Vol 7, No.2: 4. PoliteknikKesehatan Kementerian Kesehatan Tanjungkarang.

Almatsier, Sunita, dkk. 2011. Gizi Seimbang Dalam Daur Kehidupan. Jakarta, PT. Gramedia Pustaka Utama.

Anwar. 2014. Pneumonia pada Anak Balita di Indonesia. Kesmas, Jurnal Kesehatan Masyarakat Nasional Vol. 8, No. 8, Mei 2014. Pusat Teknologi Intervensi Kesehatan Masyarakat Badan Penelitian dan Pengembangan Kesehatan Kementerian Kesehatan RI.

Bustan, M.N. 2012. Epidemiologi Penyakit Tidak Menular. Rineka Cipta. Jakarta.

Chandra, B, 2006. Metodologi Penelitian Kesehatan, Palembang : Penerbit: Buku Kedokteran ECG. 
Dinkes Nagan Raya. 2016. Profil Kesehatan Kabupaten Aceh Barat Tahun 2015. Nagan Raya.

Dinkes Aceh. 2012. Profil Kesehatan Provinsi Aceh Tahun 2011. Aceh. . 2013. Profil Kesehatan Provinsi Aceh Tahun 2012. Aceh. . 2014. Profil Kesehatan Provinsi Aceh Tahun 2013. Aceh.

Ellya, dkk,. 2011. ISO Farmakoterapi. Jakarta: PT. ISFI Penerbitan.

Ellya, Eva Sibagariang, Dkk. 2010. Kesehatan Reproduksi Wanita. Jakarta ;. TIM.

Fibrila. 2015. Hubungan usia anak, jenis kelamin dan berat badan Lahir anak dengan kejadian ispa. Jurnal Kesehatan Metro Sai Wawai Volume VIII No.2 Edisi Des 2015, ISSN: 19779-469X. Politeknik Kesehatan Tajungkarang

Fuad. 2013. Infeksi Saluran Pernafasan Akut (ISPA). Jakarta : Salemba Medika

Hariani. 2014. Hubungan Status Imunisasi, Status Gizi, Dan Asap Rokok Dengan Kejadian ISPA Pada Anak Dipuskesmas Segeri Pangkep. Jurnal ilmiah kesehatan Diagnosis Volume 5 Nomor 5 Tahun 2014 • ISSN : 2302-1721. STIKES Nani Hasanuddin Makassar. 